\title{
Landsat 7 Imagery Interpretation for Mapping Potential Hazard of Landslide in Batu City Area of East Java Province, Indonesia
}

\author{
Rudi Hartono \\ Department of Geography \\ Faculty of Social Science \\ State University of Malang \\ Malang, Indonesia, \\ Corresponding email: rudi.hartono.fis@um.ac.id
}

\begin{abstract}
Avalanche is a mass movement of soil or rock down a slope under the influence of gravity (Zhou et al. 2015). The topography of Batu City has a character that can trigger landslides. Landslide disaster that occurred in the region always cause material losses and casualties. This research aims to create a map of potential hazard landslide area, identifying types of landslide, making landslide susceptibility map. Mapping of landslide hazard areas is the first step in disaster risk reduction and it is essential to do. The products of this research are landslide research report incorporating maps and a journal article. The selected research methods, that are interpretation of Landsat 7 satellite imagery of 432 band primary data causes landslides, and analyzing the soil data, interpreting of maps, and scoring variables of landslides. The ArcView 3.2 software is used in the analysis of the map. The landslide variables evaluated are: 1) soil texture, 2) soil permeability and plasticity index, 3) bedding rock slope, 4) the degree of weathering, 5) muscular density and depth of weathering, 6) existence of spring/seepage, 7) slope, and 8) presence or absence of cutting slopes. The results showed Landsat 7 imagery of bands 432 scale 1: 11.000 - 1: 15.000 objects can be interpreted such as: 1) residential, open land, 2) irrigated rice, 3) lowland, 4) upland, 4) orchard, 5) landslide slope, 6) mixed forest, 7) pine forest and 8) agroforestry forest (Stumpf, Malet, and Delacourt 2017).
\end{abstract}

\section{Keywords -Landsat imagery, landslide}

\section{INTRODUCTION}

Avalanche is a process of displacement or movement of soil with sloping or vertical direction from its original position as a result of gravity. Landslides can occur if the intensity of heavy rainfall, conditions which tilt up steep slopes, thick weathering, rocks and varied geological structure and land use are less appropriate to the characteristics of land (Sutikno, in Rahman 2010). Landslides generally occur in the rainy season, so the impact is not only happening in the local area (on site), but also on the downstream (off site). The impact of landslides in the form of sediment results to be sufficiently large for a particular rain event. In principle landslides occurred due to disruption of the balance land slopes due to the influence of the forces originating from the slopes and the forces come from outside the slopes (Karnawati in Prijono., 2009). The style of the exterior slopes influenced by the slope, the influence of water, and land use change, while the style of the slope is affected by soil physical properties (Mwaniki et al. 2015).

The Batu City is divided into 46 units of land consisting of 12 individual units have the low-rank potential landslide (L), 30 individual units have the medium rank of potential landslides (M), and 4 units of land located on the status of high potential rank of landslides $(\mathrm{H})$. As Stated by Masaba, villages tend to have high rank of landslide (Masaba et al., n.d.), in this area land with the high rank of landslide potential area of $39.5745 \mathrm{~km}^{2}$ located in the villages of western Songgokerto, Punten, Gunungsari and west of Tulungrejo, west of Pandesari, and Pesanggrahan west., Medium/middle rank of landslide potential area of $128.7574 \mathrm{~km}^{2}$ located in the villages Bumiaji, Pandanrejo, Sidomulyo, Bulukerto, Sumbergondo, Sisir, Temas, Songgokerto, Beji, Torongrejo, Giripurno, Ngaglik, Sumberejo, Oro-oro Ombo, Junrejo, Torongrejo, Pendem, Beji, Mojorejo, Dadaprejo, partly of Tlekung, and the low rank of landslides of $30.5745 \mathrm{~km}^{2}$ located in part of the Tulungrejo middle, and Sidomulyo south.

Batu City astronomically located between $112^{\circ} 17^{\prime} 10,90 "$ until $112^{\circ} 57$ 'East Longitude and $7^{\circ} 44^{\prime} 55^{\prime} 00^{\prime}$ 'until $8^{\circ} 26{ }^{\prime} 35,45^{\prime}$ 'South Latitude. Location of Kota Batu area is on the slopes of Mount Welirang and Mount Arjuno and lead this region has a steep slope with erodible land on it. Besides its mountainous morphology lead this region rainfall is comparatively higher than 
in plain areas. According Sutikno (1994, in Rahman, 2010), land landslides can occur in areas that have such characteristics.

\section{METHOD}

This study aims to: 1) determining the ability of Landsat 7 bands 432 a scale of 1: 11,000 and 1: 15,000 in the interpretation of landslides variables, 2) determining the type of land units, 3) Knowing the distribution of landslide hazard area, 4) knowing the potential landslides in Batu City. The study was a descriptive survey describing the results interpretation maps and Landsat 7 image band 432 for creating maps of potential landslide-prone areas. Laboratory testing of soil samples which consist of: 1) texture, 2) permeability, and 3) soil plasticity index, made to complement the properties of the soil.

Landsat 7 image interpretation methods band 432 that is the interpretation on-screen display image on the computer screen and manual interpretation of the printed image. Potential landslides assessed based on the unit of land and the characterized by 10 variables by scoring. The 10 variables of landslide potential namely: 1) soil texture, 2) permeability, 3) the plasticity index of land, 4) the slope of the layering of rock, 5) the degree of weathering, 6) joint density 7) the depth of weathering, 8) existence of spring water seepage ,9) slope, and 10) the existence of excavation / cutting slopes.

As noted in the research methods that interpretation of Landsat 7 of 432 bands performed on a screen on the computer screen as well as interpretations of the print-out image. Interpretation using the 8 elements of image interpretation that includes: 1) color, 2) texture, 3) site, 4) pattern, 5) height/size, 6) shadow, 7) shape and 8) associates objects in the image. The imagery used scales ranging from 1: 11.000 to $1: 15.000$. Image recording date of November 31, 2015, thus not many changes compared to the current land cover.

The combination of 432 bands was a visible/panchromatic so that the appearance color of the object in the image is similar to the color of actual objects. Correction to the image geometric was done by selecting four objects in the image and look for the object in the field and recorded its coordinates and then plotted on a topographical map of 1: 25.000. Thus the image coordinates are already bounded by map coordinates. This treatment is done by software ArcView.3.2 on the menu register transform coordinates. At the time of the register looks RMS (Root Mean Square) error shows the number 0.07 which means the image coordinates can be used.

There are 10 variables of landslides used in determining level of its vulnerability. The lowest score is 10 and the highest one is
40. Classification of vulnerability to landslides are divided into three classes, as for intervals in each class of vulnerability to landslides can be sought in a way as following:

TABLE 1. LANDSLIDE CLASSIFICATION SCORE

\begin{tabular}{ccc}
\hline Class & Interval & Landslide Rank \\
\hline I & $10-19$ & Low (L) \\
II & $20-29$ & Middle (M) \\
III & $30-40$ & High (H) \\
\hline
\end{tabular}

\section{FINDING AND DISCUSSION}

Based on interpretation of Landsat imagery of band 432 had been done then the variable land use and land cover is a variable that is directly visible in the image so that the variable most easily interpretable. The next variable is the pattern of relief because it and the slope associated with land use. Of the relief pattern is then viewed the branching pattern of the river because the river can also be seen directly on the image. After that interpreted the ground color and shape of the land and finally delineated (drawn borders) unit of land. Land unit is used as a unit of land assessment of potential landslides.

Image interpretation is devoted to the interpretation of the object which are variables of landslides, namely: 1) the land use and types of vegetation cover, 2) slope, 3) river and stream density, 4) ground color appearance 5) rock structure and shape of the land. Thus of the 10 variables mentioned above can only be interpreted 5 variables. For variable soil texture, soil plasticity index and permeability of the soil tested in the laboratory and the depth of weathering and excavation / cutting slope, joint density observed in the field. 


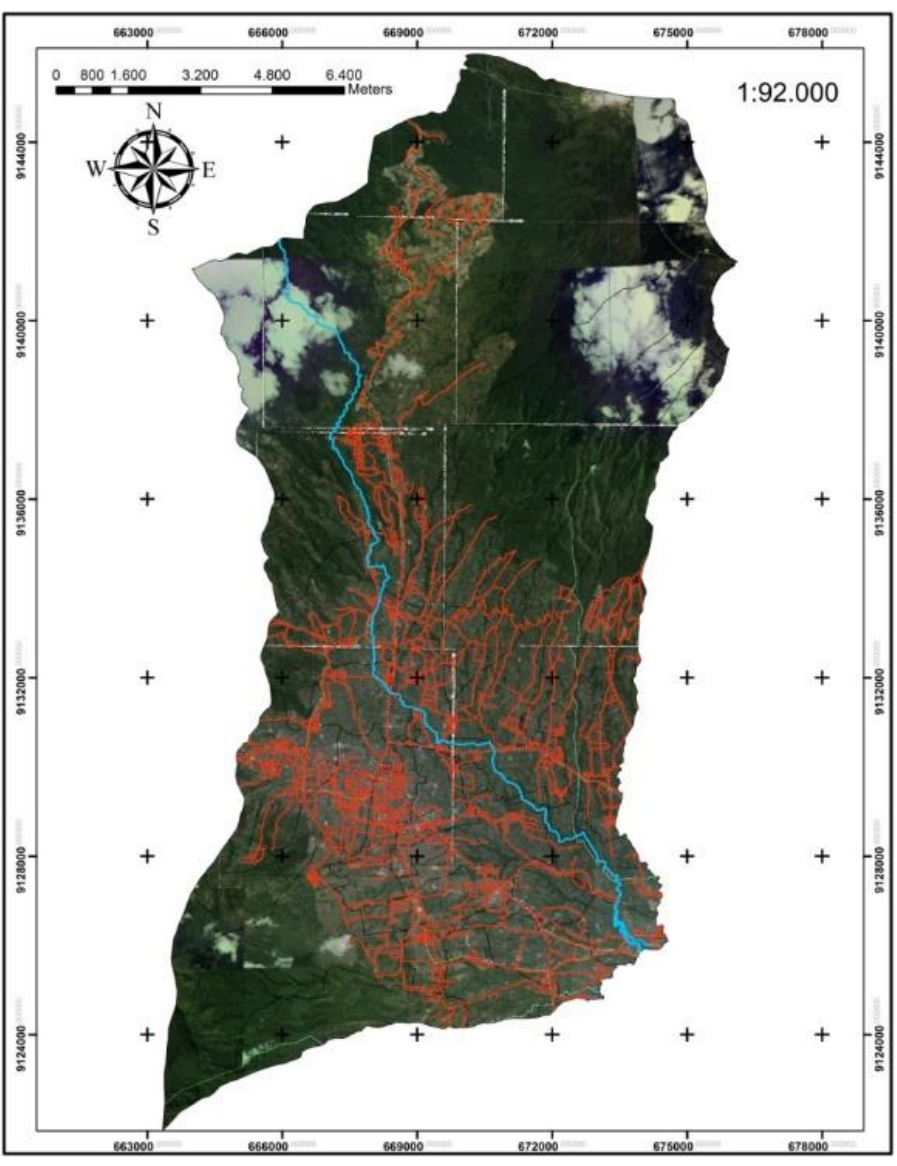

Fig. 1. The Landsat 7 band 432 coverage of research area

Based on the interpretation of sample points of Landsat 7 of bands 432 research areas, interpreted landuse objects are: 1) settlement, 2) the clearing land, 3) irrigated fields, 4) rainfed, 5) moor, 6) breeding land, 7) garden, 8) landslide slope, 9) natural forest / mixed, 10) "sengon" forest and 11) pine forests.

Based on the analysis of the current map with geoprocessing techniques intersect and overlay multiple layers acquired 46 land units from a combination of 7 landforms and land use. That land units are: 9 units of volcanics footslope (V7), 13 units of fluvial plains (F5), 6 units of lava tuff deposite (V5), 7 units plains between the mountains (D6), 5 units of lower volcanics slope (V4), 4 units of middle volcanic slopes (V3) and 2 units upper volcanic slopes (V2).

Potential landslides as of secondary rank (M) coverage of area of $128.7574 \mathrm{~km}^{2}$ or $64.68 \%$ of the entire territory of Batu. Potential landslide is located on land: V5-Tg, V5-Kb, D6-Pk, V4-Pk, Pk-V3, V7-Kb, V7-Sw, V7-Tg, V2-Ht. The villages are located in this land are: Bumiaji, Pandanrejo, Sidomulyo, Bulukerto, Sumbergondo, Sisir, Temas, Songgokerto, Beji, Torongrejo, Giripurno, Ngaglik, Sumberejo, Oro-oro Ombo,
Junrejo, Torongrejo, Pendem , Beji, Mojorejo, Dadaprejo, and partly Tlekung village. Potential landslide of low rank (L) located on land units: plains between the mountains (D6) with residential land use Plains Fluvial (F5) with the use of settlement land, fields, gardens and open land. The village is located in this area are: western part of Pandesari, Tulungrejo middle, Sidomulyo south. The land area of low rank for landslides is 30 , $5745 \mathrm{~km}^{2}$ or $15.35 \%$ of the area of Batu.

Based on the analysis overlay of maps and interpretation of Landsat 7 bands 432 was not able to conclude an association for land use, landforms, for example: the forest is not always located on land form the upper slope (V2), the middle slopes (V3) or downslope ( V4), but forests also found at Fluvial Plain (F5) and Volcanic foot Slope (V7). Based on the scoring of the variables is known that the landslide potential divided into: 12 individual units have a low potential for landslides (L), 30 individual units have the medium potential landslides $(\mathrm{M})$, and 4 units of land located on the status of high potential $(\mathrm{H})$ for landslides.

Potential landslides highland located on land form: middle volcanic slope (V3) with the use of wetland $(\mathrm{Sw})$, garden $(\mathrm{Kb})$, moor (Tg) and upper of volcanic Slope (V2) with the use of forest land (Ht). The land area entirely is $39.7556 \mathrm{~km}^{2}$ or $19.97 \%$ of the area of Batu. Landform, of middle volcanic slopes located in the western part of the city that is in the village of west Songgokerto, Punten, Gunungsari and western Tulungrejo, western Pandesari, and Pesanggrahan. The land use of forest dominant here, but was not conserved properly. Terrace bench is a common form of conservation here, but there are some forests felled and the land is left alone.

Based on field measurements and observations, landslides in the village of Gunungsari had the type of debris (debris fall) which was not found source rock is exposed, so there is no impermeable layer that serves as a sliding plane. Landslides occurred on slopes of $36^{\circ}$ in the absence of shrubs / bushes at the base of the forest and forest plants are also very rare because felled. An avalanche of about $45 \mathrm{~m}^{2}$ volume found in the edge side of the road.

The occurrence of landslides of the road connected Batu Pujon triggered by heavy rains. This avalanche-type slider (slide) in which a layer of andesite beneath the road acts as a sliding plane. Here measured slope steep $56^{\circ}$ category. As a result of landslides, half the road is destroyed 9 meters along, as stated by Arsyad, Karnawati: there are cracks in the soil on impermeable layer the angled slopes that would not hold water (Arsyad, 1989),(Karnawati, 2005).

\section{CONCLUSIONS AND SUGGESTIONS}

The landslide variables which can easily interpretated are : 1) the land use and types of vegetation cover, 2) slope, 3) river and stream density, 4) ground color appearance 5) rock structure and 
shape of the land. Based on field measurements and observations, landslides in the village of Gunungsari had the type of debris (debris fall) which was not found source rock is exposed and landslide in Songgoriti has the type of slide. There should be conducted another research with another method of imagery use.

\section{REFERENCES}

[1] Arsyad, S, 1980, "Soil Conservation", IPB: Bogor.

[2] Karnawati, D, 2005, "Mass Movement of Natural Disasters in Indonesia and Abatement Efforts", Yogyakarta: Jur. Geology FT UGM.

[3] Masaba, Sowedi, David N. Mungai, Moses Isabirye, and Haroonah Nsubuga. n.d., "Implementation of Landslide Disaster Risk Reduction Policy in Uganda", International Journal of Disaster Risk Reduction. doi:10.1016/j.ijdrr.2017.01.019.

[4] Mwaniki, Mercy W., Nathan O. Agutu, John G. Mbaka, Thomas G. Ngigi, and Edward H. Waithaka., 2015, "Landslide Scar/Soil Erodibility Mapping Using Landsat TM/ETM+ Bands 7 and 3 Normalised Difference Index: A Case Study of Central Region of Kenya." Applied Geography 64 (October): 108-20. doi:10.1016/j.apgeog.2015.09.009.

[5] Rahman, Zarkasyi, A., 2015, "Kajian Mitigasi Bencana Tanah Longsor di Kabupaten Banjarnegara", GEMA REPUBLIKA. Jurnal Manajemen dan Kebijakan Publik. Vol 1. No. 01. ISSN 2460-9714.

[6] Prijono, 2009, "Analisis Penyebab Longsor Di Kawasan Perbukitan Malang Selatan, Kecamatan Pagak (Analysis of Landslide Factors in South Hilly Area of Pagak Subdictrict)", AGRITEK Vol. 17 No.2 Maret 2009 ISSN.0852-5426.

[7] Stumpf, André, Jean-Philippe Malet, and Christophe Delacourt, 2017, "Correlation of Satellite Image Time-Series for the Detection and Monitoring of Slow-Moving Landslides", Remote Sensing of Environment 189 (February): 40-55. doi:10.1016 j.rse.2016.11.007.

[8] Zhou, Jia-wen, Kang-xin Huang, Chong Shi, Ming-hui Hao, and Chao-xu Guo, 2015, "Discrete Element Modeling of the Mass Movement and Loose Material Supplying the Gully Process of a Debris Avalanche in the Bayi Gully, Southwest China", Journal of Asian Earth Sciences 99 (March): 95-111. doi:10.1016 /j.jseaes.2014.12.008. 